\title{
The culture of patient safety from the perspective of the pediatric emergency nursing team*
}

\section{Cultura de segurança do paciente na perspectiva da equipe de enfermagem de emergências pediátricas}

Cultura de seguridad del paciente en la perspectiva del equipo de enfermería de urgencias pediátricas

Taise Rocha Macedo ${ }^{1}$, Patricia Kuerten Rocha², Andreia Tomazoni ${ }^{3}$, Sabrina de Souza ${ }^{3}$, Jane Cristina Anders², Karri Davis ${ }^{4}$

How to cite this article:

Macedo TR, Rocha PK, Tomazoni A, Souza S, Anders JC, Davis K. The culture of patient safety from the perspective of the pediatric emergency nursing team. Rev Esc Enferm USP. 2016;50(5):756-762. DOI: http://dx.doi.org/10.1590/S0080-623420160000600007

*Extracted from the dissertation "Cultura de Segurança do Paciente em Unidades de Emergência Pediátrica: perspectivas da equipe de enfermagem", Universidade Federal de Santa Catarina, Programa de Pós-Graduação em Enfermagem, 2015.

${ }^{1}$ Universidade Federal de Santa Catarina, Programa de Pós-Graduação em Enfermagem, Florianópolis, SC, Brazil.

${ }^{2}$ Universidade Federal de Santa Catarina, Departamento de Enfermagem, Florianópolis, SC, Brazil.

${ }^{3}$ Universidade Federal de Santa Catarina, Hospital Universitário, Residência Multiprofissional na Área de Saúde da Mulher e da Criança, Florianópolis, SC, Brazil.

${ }^{4}$ Fairfield University, New Haven,

Connecticut, United States of America.

\begin{abstract}
Objective: To identify the patient safety culture in pediatric emergencies from the perspective of the nursing team. Method: A quantitative, cross-sectional survey research study with a sample composed of 75 professionals of the nursing team. Data was collected between September and November 2014 in three Pediatric Emergency units by applying the Hospital Survey on Patient Safety Culture instrument. Data were submitted to descriptive analysis. Results: Strong areas for patient safety were not found, with areas identified having potential being: Expectations and actions from supervisors/management to promote patient safety and teamwork. Areas identified as critical were: Non-punitive response to error and support from hospital management for patient safety. The study found a gap between the safety culture and pediatric emergencies, but it found possibilities of transformation that will contribute to the safety of pediatric patients. Conclusion: Nursing professionals need to become protagonists in the process of replacing the current paradigm for a culture focused on safety. The replication of this study in other institutions is suggested in order to improve the current health care scenario.
\end{abstract}

\section{DESCRIPTORS}

Patient Safety; Organizational Culture; Nursing, Team; Pediatric Nursing. 


\section{INTRODUCTION}

Concerns involving the patient safety issue have broadened from the publication of the report To Err is Human: Building a Safer Health Care System, in 1999, when the study alerted health professionals and society about errors involving health care and the damage that can reach patients, making this issue a priority on the agendas of many countries ${ }^{(1)}$.

Current data show that the amount of deaths resulting from adverse events in health is alarming. It is estimated that approximately 400,000 patients die each year due to preventable adverse events, and between 2 and 4 million adverse events generate serious consequences to patient health without leading to death. When compared to adults, hospitalized children are three times more likely to suffer injury ${ }^{(2-3)}$.

In this sense, the World Health Organization (WHO) sought to develop global policies that would improve the care offered in health services, reversing this drastic situation. In 2004, The World Alliance for Patient Safety program was created, recommending attention to the issues surrounding patient safety ${ }^{(4)}$ to its member countries.

In the national context, the Ministry of Health established the National Policy of Patient Safety on April 1, 2013, seeking to contribute to the qualification of health care in all establishments, and demonstrating the State's concern regarding this theme ${ }^{(5)}$.

However, in order for patient safety to truly occur, safety culture needs to be structured within the institutions, corresponding to establishing a proper process of communication, trust, organizational learning, collective commitment relating to safety aspects, leadership, the importance of this subject, and a non-punitive approach to error ${ }^{(6)}$.

Identifying and evaluating safety culture are performed through applying questionnaires to workers and managers on their actions and perceptions of patient safety, and how it is prioritized and managed ${ }^{(7)}$. In this study, the Hospital Survey on Patient Safety Culture (HSOPSC) instrument was used to carry out the identification of patient safety culture.

This instrument was adapted and used in an American Pediatric Hospital, suggesting that the assessment of the safety culture allows us to identify opportunities for improvement in the institution's safety culture, thus preventing and avoiding errors. In the national context, its application in Neonatal Intensive Care Units has indicated the need for cultural change in this scenario. Investigations conducted in Pediatric Emergency units using the HSOPSC instrument ${ }^{(8-9)}$ have not yet been found.

Addressing the safety culture in Pediatric Emergency units is necessary, since these sectors are prone to errors which may be related to the physical and organizational structure of these units, to the specifics related to the treatment of these patients, or the lack of incentive of studies related to this area ${ }^{(10)}$.

Involving nursing in this approach is crucial, considering this category is the largest workforce in health institutions, and discussions involving them can generate changes in the workplace, thereby modifying the health system and improving patient safety ${ }^{(11)}$.
Considering the necessity of understanding the patient safety culture that constitutes Pediatric Emergency units in order to improve the current scenario, this research aims to identify the patient safety culture in pediatric emergency units from the perspective of the nursing team through implementing the Hospital Survey on Patient Safety Culture instrument (HSOPSC).

\section{METHOD}

This is a descriptive, quantitative cross-sectional survey study, carried out in three Pediatric Emergency units of the Greater Florianópolis area in Santa Catarina, Brazil.

The population was composed of 91 nursing team professionals of the three participating units. An intentional, non-probabilistic sample followed the following inclusion criteria: being a nurse, nursing technician or nursing assistant and exercising these functions in a pediatric emergency unit during the period of data collection; admitted professionals and having been situated in the industry for more than two months (due to the necessary adaptation period, where the employee may not have complete knowledge concerning the unit). Exclusion criteria were: nursing professionals on vacation, sick leave, pregnancy/maternity leave or sabbatical during the period of data collection; nursing professionals who were not situated in said unit; or instruments being less than half filled out. According to these criteria, 77 participants were invited to participate in the study. Two individuals refused to participate in the study from this initial total, therefore the final sample was comprised of 75 subjects.

According to data from the National Health Facilities Census (Cadastro Nacional de Estabelecimento de Saúde CNES), the pediatric emergency units participating in the study had the following classification: Pediatric Emergency A (PEMG A), classified as a pediatric emergency room; Pediatric Emergency B (PEMG B), with no information of this service in the registry; Pediatric Emergency C (PEMG C), classified as stabilization of critical condition patients, pediatric, orthopedic injury and trauma, cardiovascular, neurological and neurosurgical emergency room ${ }^{(12)}$.

Regarding the Internal Center of Patient Safety (Núcleos Internos de Segurança do Paciente - NISP), they began to be structured in Hospital A in 2014; the NISP has been instituted since 2010 in Hospital B; and the NISP was implemented in 2013 in Hospital C. All institutions have implemented the system for reporting adverse events.

Data collection took place between September and November 2014 through implementation of the HSOPSC instrument validated for the Brazilian hospital setting. Its application was implemented after authorization from the original authors and followed the recommendations proposed by the Agency for Healthcare Research and Quality (AHRQ) ${ }^{(13-14)}$.

The instrument consists of 42 questions that make up 12 dimensions of patient safety culture. It has an item in which the subjects attribute a score to patient safety of their institution; one item in which the participant reports the number of reported events; and eight items in which participants are characterized ${ }^{(14)}$. 
These items are grouped into three variables; one variable for professional characteristics of the subject, comprised of the following items: working experience in the profession, in the hospital and in the unit, weekly working hours and working title/position at the hospital; safety culture variables comprised by the dimensions: teamwork in the unit, expectations and actions of the supervisors/management for (promoting) patient safety, organizational learning/continuous improvement, feedback and communication about errors, open communication, number of staff, non-punitive response to error, hospital management support for patient safety; teamwork (between the units), internal transfers and shift change; outcome variables composed by the dimensions of general perception of patient safety and frequency of reported events, and also the number of reported events and patient safety score items ${ }^{(14)}$.

For data collection, the project was initially presented to nursing managers of the participating units in order to investigate the possibility of its development and to obtain authorization to conduct the study. Subsequently, the study was individually presented to each participant according to their availability in the unit. After individuals expressed their acceptance to participate in the survey, they were presented with the Clear and Informed Consent Form and an opaque envelope containing the data collection instrument. The instrument was completed by individual participants, then inserted back in the envelope and anonymously deposited in a closed box available in the unit. The envelopes that had been filled and placed in the box were collected by the researcher at the end of each period.

The responses were tabulated and descriptively analyzed in Microsoft Excel 2014, emphasizing that not all items of the 12 dimensions were answered on all instruments, with a difference in the overall answers for each dimension. The obtained responses were grouped into three categories: positive responses (I totally agree, I agree, Always and Often), negative responses (I totally disagree, I disagree, Never and Rarely) and neutral responses (I neither agree nor disagree). In order to ensure more consistent responses, the instrument consists of 18 reverse questions, in which when the participant disagrees with a negative statement, they are expressing a positive opinion ${ }^{(14)}$.

According to guidelines proposed by the AHRQ, the areas of strength are the dimensions in which $75 \%$ of subjects responded positively to positive questions and negatively to negative questions, and critical areas are those in which the subjects attribute $50 \%$ or more of negative responses to positive questions or positive responses to negative questions ${ }^{(14)}$.

Ethical issues followed the recommendations of the National Health Council Resolution 466/2012, and the research project was submitted and approved in the Plataforma Brasil under Protocol No. 35231514.1.0000.5361 ${ }^{(15)}$.

\section{RESULTS}

The study included 75 professionals of the nursing team from three Pediatric Emergency Units in the Greater Florianópolis region. The results show that among the study participants, 58 (77\%) have secondary education. The data also reveals that more than half of the participants have more than 10 years of experience in the profession, and a significant number of professionals have worked at the units in question for a period less than or equal to 5 years, with a workload ranging from 20 to 79 hours per week (Table 1).

Table 1 - Professional characteristics of Patient Safety Culture research subjects at Pediatric Emergency Units of Public Hospitals in the Greater Florianópolis area - Florianópolis, SC, Brazil, 2014.

\begin{tabular}{|c|c|c|c|}
\hline Professional characteristics of the Subjects & & $\mathbf{N}$ & $\%$ \\
\hline \multirow{3}{*}{ Work Title/Position } & Nurse & 17 & 23 \\
\hline & Nursing Technician & 40 & 53 \\
\hline & Nursing Assistant & 18 & 24 \\
\hline \multirow{5}{*}{ Working time/experience in the profession } & 1 to 5 years & 14 & 19 \\
\hline & 6 to 10 years & 18 & 24 \\
\hline & 11 to 15 years & 8 & 11 \\
\hline & 16 to 20 years & 10 & 11 \\
\hline & $>20$ years & 24 & 32 \\
\hline \multirow{6}{*}{ Working time/experience in the Unit } & $<1$ year & 5 & 6 \\
\hline & 1 to 5 years & 38 & 51 \\
\hline & 6 to 10 years & 8 & 11 \\
\hline & 11 to 15 years & 6 & 8 \\
\hline & 16 to 20 years & 10 & 13 \\
\hline & 21 years or more & 8 & 11 \\
\hline \multirow{4}{*}{ Weekly working hours } & Less than 20 hours & 1 & 1 \\
\hline & Between 20 and 39 hours & 44 & 57 \\
\hline & Between 40 and 59 hours & 24 & 31 \\
\hline & Between 60 and 79 hours & 6 & 8 \\
\hline
\end{tabular}


By analyzing the 12 dimensions of patient safety culture, the professionals evaluated 1,426 (45\%) responses as positive, 1,092 (35\%) as negative responses and $612(19 \%)$ responses as neutral. After the items corresponding to each dimension of patient safety culture were grouped, the mean percentage of positive, negative and neutral responses for each of the 12 dimensions of patient safety culture was determined (Figure 1).

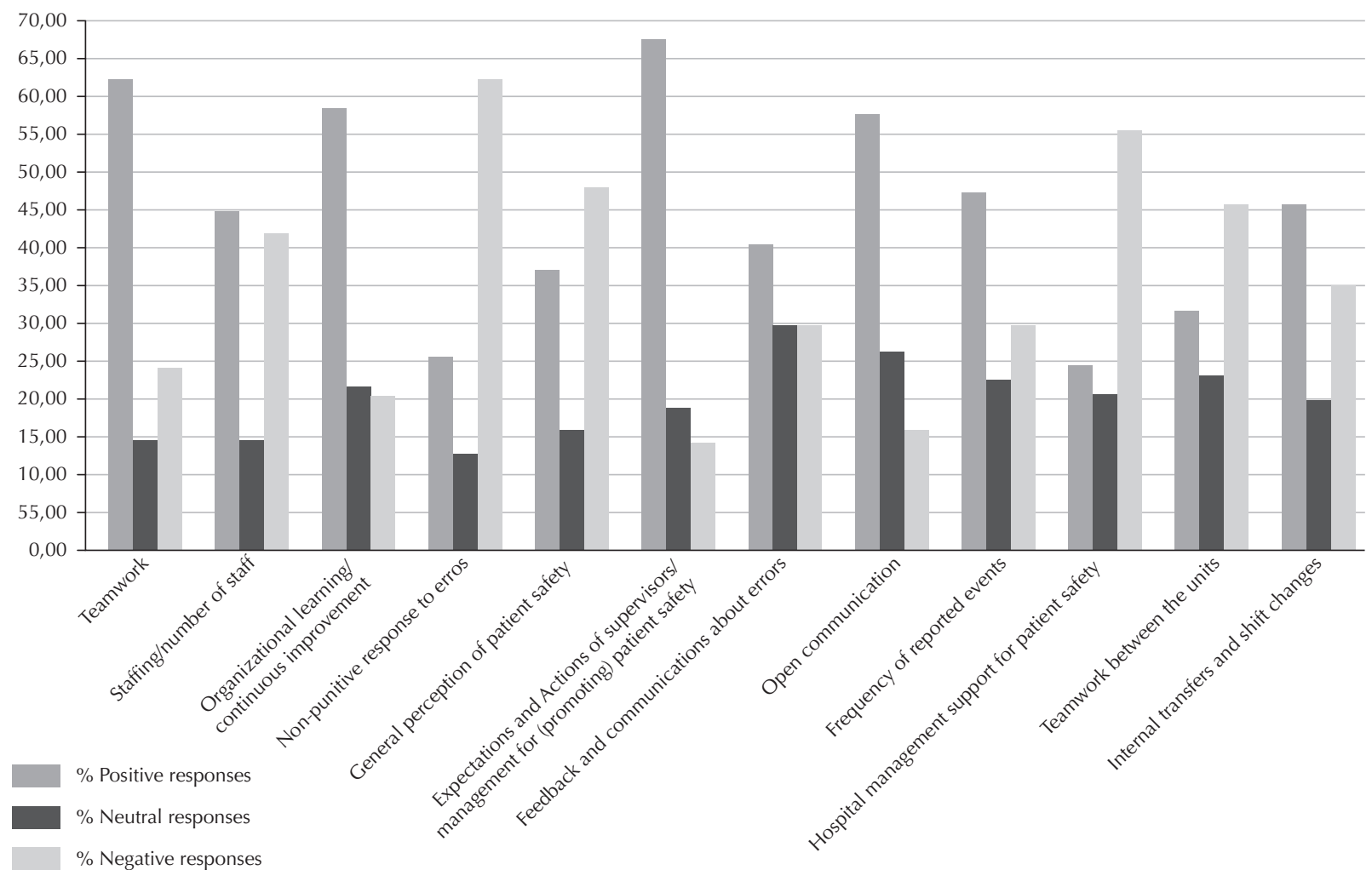

Figure 1 - Percentage of positive, neutral and negative responses of the twelve dimensions of patient safety culture according to HSOPSC in Pediatric Emergency Units of Public Hospitals in the Greater Florianópolis region - Florianópolis, SC, Brazil, 2014.

Thus, according to the guidelines of the AHRQ this study did not identify any dimension being classified as strong for patient safety, corresponding to a positive response with a percentage above $75 \%{ }^{(14)}$.

Dimensions with the highest positive rating are presented below. The first highlight of the study is for the dimension Expectations and actions of supervisors/management for promoting patient safety, which obtained 201 (67\%) positive responses. This dimension is linked to the concerns and attitudes that supervisors/management develop to promote patient safety ${ }^{(14)}$.

It is worth mentioning that this dimension is composed of four items of the instrument, and the item which stood out was 'Whenever pressure increases, my supervisor/manager wants us to work faster, even if that means skipping steps,' with $63(84 \%)$ positive responses. This indicates that these professionals strongly disagreed with the statement, and indicated it as an item of strength for patient safety.

The second dimension that obtained the highest number of responses with 185 (62\%) positive responses was Teamwork, which deals with support and respect among employees and work carried out as a team. This dimension is composed of three items, where the item 'When there is too much work to be done quickly, we work together as a team in order to complete it properly, 'stood out, with 68 (91\%) positive responses ${ }^{(14)}$.

The third outstanding dimension composed of three items was 'Organizational learning/continuous improvement,' with $130(58 \%)$ positive responses. This dimension identifies the existence of a learning culture in which the errors are evaluated and reversed into positive changes that lead to improvements. The highlight of this dimension was the item We are actively doing things to improve patient safety, in which $45(60 \%)$ participants rated it positively, demonstrating its potential to become a strength area for patient safety ${ }^{(14)}$.

However, two of the dimensions received negative assessment by $50 \%$ or more of the responses, and so therefore are identified as critical areas for patient safety. The first dimension that received the highest proportion of negative responses was 'Non-punitive response to errors,' obtaining 138 (61\%) negative responses. This dimension assesses how professionals observe the errors that occurred, how they are communicated and not used against them or kept in their professional file. This dimension is composed of three items, and the item 'When an event is reported, it seems that the focus lies on the person and not the problem'received the highest number of responses agreeing and/or totally agreeing with 48 (64\%) responses ${ }^{(14)}$.

The second worse dimension evaluated was Support of hospital management for patient safety, in which 123 (55\%) professionals responded negatively. This dimension shows how the hospital provides a suitable working environment for the promotion of patient safety, showing that patient safety is a priority in their actions, and is composed of three items. The item with the highest negative rating in this dimension 
was 'The leadership of the hospital only seems interested in patient safety when some adverse event happens,' with 45 (60\%) participants agreeing and/or totally agreeing with the statement ${ }^{(14)}$.

As previously mentioned, in addition to the evaluation of the safety culture dimensions, the instrument also evaluates two items that structure the result of the safety culture variable; the first being awarding a grade on patient safety in their work unit in the hospital according to individual perception, and the second is the amount of adverse events reported by the professional in the last 12 months.

The score on patient safety can be assigned according to a Likert scale, as presented in Figure 2. In this way, the data show that $28(37 \%)$ and $26(35 \%)$ participants evaluated patient safety in their unit as regular and very good, respectively.

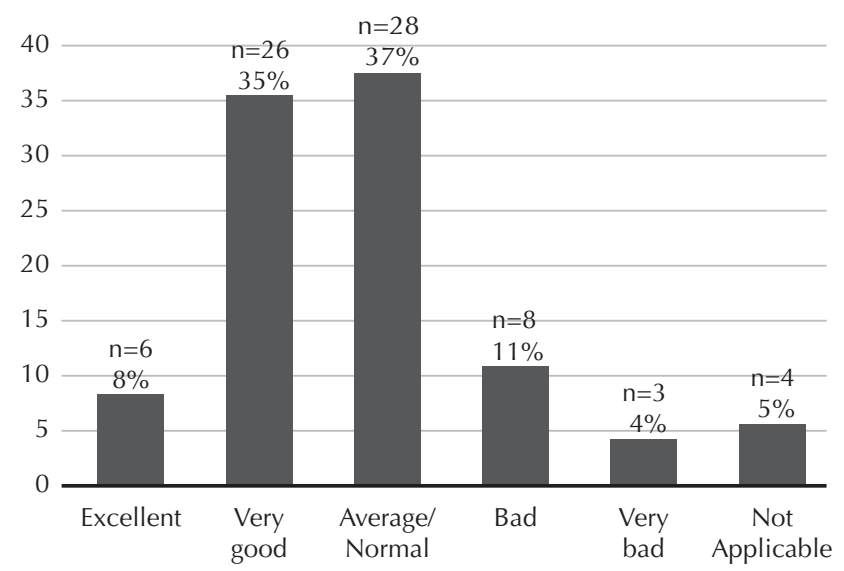

Figure 2 - Mean percentage of responses about score on Patient safety in the Pediatric Emergency Units of Public Hospitals in the Greater Florianópolis Region - Florianópolis, SC, Brazil, 2014.

Regarding the second item of the results variable dealing with the number of reported adverse events, the data show that most of the participants $(72-96 \%)$ reported less than five adverse events in the last 12 months. Of these, 34 (45\%) reported no event at this period of time (Figure 3).

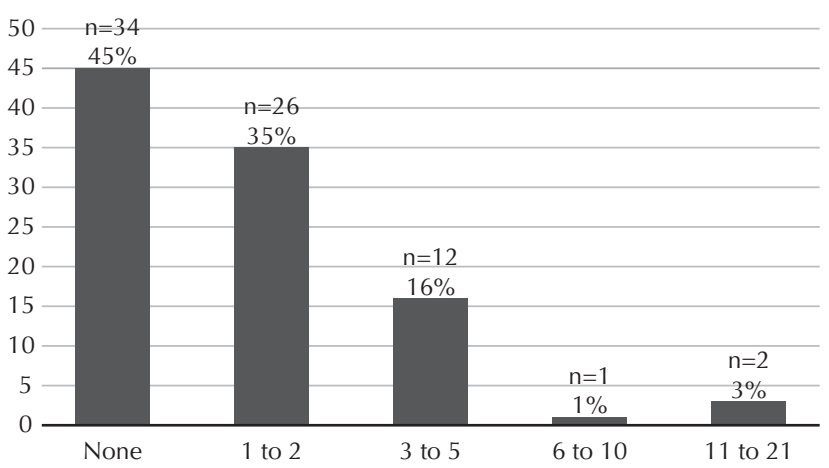

Figure 3 - Mean percentage of responses about the number of adverse events reported in the last 12 months in the Pediatric Emergency Units of Public Hospitals in the Greater Florianópolis region - Florianópolis, SC, Brazil, 2014.

\section{DISCUSSION}

In this study, none of the areas were classified as being a strength for patient safety, showing that safety culture is not fully established in these units. However, the areas
Expectations and actions of supervisors/management for promoting patient safety and Teamwork were highlighted as the dimensions with better positive evaluation indexes, therefore being areas which can become strengths in the context of patient safety culture in these Pediatric Emergency units.

The absence of strength areas for patient safety may be tied to the recent concern about the theme, reinforced by the establishment time of Patient Safety Centers, which are mainly structured on services after publication of the National Program for Patient Safety (which took place recently in 2013) $)^{(5)}$.

The dimensions indicated in this study as having potential to become areas of strength for safety culture were also evaluated as areas of strength for patient safety in an American study conducted in 680 general hospitals, with 447,584 professionals using HSOPSC in which 82\% of responses were positive for Teamwork and 78\% for Expectations and Actions of supervisors/management for (promoting) patient safety. In China, a study conducted in seven general hospitals with 463 nurses found an $87 \%$ positive assessment for the dimension Teamwork ${ }^{(14,16)}$.

Despite the cultural differences in these countries, the high percentage of positive responses attributed to the aforementioned dimensions allow them to be recognized as pioneering areas of safety culture within institutions in different contexts, reinforcing concerns by supervisors/ managers to strengthen patient safety by using appropriate procedures and team contributions.

Considering that safety culture is not strengthened in these pediatric scenarios, there is the need to work on the areas that have the potential to become a strength for safety culture in order to consolidate them as highlighted areas within the safety culture of the institutions, thus contributing to the qualification of the work in these units.

In contrast, critical areas for patient safety were predominant, namely those that received $50 \%$ or more of negative responses and which must be overcome in the context of the institutions. In this study, the two dimensions with the highest negative evaluation indexes were Non-punitive response to errors and Support of hospital management for patient safety, with $61 \%$ and $55 \%$ of negative responses, respectively.

In a Brazilian study conducted in four neonatal intensive care units with 181 professionals and using the same research instrument, both of these dimensions were also appointed as being critical: Non-punitive response to errors (58\%) and Support of hospital management for patient safety (51\%). In the American report cited above, the dimension Non-punitive response to error received $65 \%$ of negative responses, also being the worst evaluated dimension ${ }^{(9,14)}$.

These results allow us to state that professionals encounter difficulties in recognizing concern on the part of the management about the issues surrounding patient safety and they reaffirm the presence of the traditional culture of blame and punishment, depicting the need to change the current culture still present in these units.

In order to modify this context/reality, it is necessary to develop mechanisms to facilitate the reporting of adverse 
events, and to develop specific printed and online instruments in which the professional defines whether or not they want to be identified. Safety centers need to work on their importance for the growth of the institution and systematically address them so that improvements in patient safety can occur.

Despite areas of strength not being evident for patient safety and rather the critical areas were more prominent, most professionals appointed patient safety as Average (37\%) and Very Good (35\%). In the aforementioned Brazilian study developed in Neonatal Intensive Care Units, most subjects assessed the patient safety as Average (45\%), Very Good (38\%) and Excellent (3\%) $)^{(9)}$.

At an international level, a Dutch study conducted in 26 emergency units with 730 professionals, the participants evaluated patient safety as Average (66\%), Very good (22\%), Excellent (1\%), Poor (10\%), and Very Poor $(1 \%)^{(17)}$.

These discrepancies found in patient safety evaluations by health professionals in different institutions, assistance contexts and countries may be associated to the level of safety culture implementation. This can stimulate reflection and criticality by professionals, thereby influencing patient safety evaluation in the places where they work.

In countries where the safety culture is already better structured and present, evaluations regarding patient safety are more insightful. In this sense, the results of this study demonstrate how much the safety culture of pediatric emergencies needs to improve, seeking to reduce hierarchy gradients, strengthen the communication processes and the work between the teams, with sufficient quantity of appropriate working and professional conditions; to discuss training environment aspects related to pediatric patients; to replace the punitive approach with the systemic approach; strengthen notification systems so that all professionals learn from the mistakes that occur in the institution, and then to outline strategies so that they do not happen again.

Regarding the reported adverse events, it was found that despite the existence of Patient Safety Centers (NISP) and notification/report systems in all institutions participating in the study, $45 \%$ of professionals had not reported any notification in the last 12 months, and 35\% had reported up to two adverse events, reinforcing that safety culture is not fully present in these units.
This reduced number of notifications may be associated with underreporting; a fact that generates damage to the entire system. In this sense, a study with Brazilian nurses on underreporting identified 115 reasons for its occurrence or the omission of communicating adverse events, where work overload, forgetfulness, lack of awareness of adverse events, fear and shame were the items which received greater emphasis for it occurring ${ }^{(18)}$.

Patient safety culture stipulates that incidents are reported, allowing for analysis and enabling the institutions to take preventive and educational measures related to them. However, in order for error notification to happen, it is necessary that the method of punishment is changed as the fear of repression makes it difficult for workers to report these events ${ }^{(19)}$.

Modifying the current paradigm, implementing and strengthening safety culture in pediatric emergency units, as well as throughout the health system are necessary actions to enforce the reporting systems, increase adverse event reporting, and promote changes in institutions aimed at reducing errors and improving patient safety, thereby qualifying all aspects of provided care.

\section{CONCLUSION}

This study has highlighted the gap between safety culture and pediatric emergency services, but has elucidated dimensions as transforming possibilities that contribute to the safety of pediatric patients.

The results point to the need to strengthen and stimulate recording of errors and adverse events in the units, thus replacing the traditional and punitive culture for safety culture, providing a work environment that values and encourages patient safety.

Environments for discussion and learning involving managers and professionals involved in the care process must be structured to ensure moments of reflection on patient safety as well as the particulars involving pediatric patients, especially in the emergency context.

It is suggested that this study be replicated in other hospitals in order to sensitize professionals about the issue and improve the understanding of the current situation of safety culture by providing subsidies for the qualification of health care.

\section{RESUMO}

Objetivo: Identificar a cultura de segurança do paciente em emergências pediátricas, na perspectiva da equipe de enfermagem. Método: Pesquisa quantitativa, tipo survey transversal. Amostra composta por 75 profissionais da equipe de enfermagem. Dados coletados entre setembro e novembro de 2014, em três Emergências Pediátricas, aplicando o instrumento Hospital Survey on Patient Safety Culture. Dados submetidos à análise descritiva. Resultados: Não foram encontradas áreas de força para a segurança do paciente, sendo identificadas áreas com potencial de assim se tornarem: Expectativas e açôes do supervisor/chefía para promoção da segurança do paciente e Trabalho em equipe. Como área crítica identificaram-se: Resposta não punitiva ao erro e Apoio da gestão hospitalar para segurança do paciente. O estudo apontou distanciamento entre a cultura de segurança e as emergências pediátricas, porém vislumbrou possibilidades de transformação, que contribuirão para segurança do paciente pediátrico. Conclusão: Os profissionais de enfermagem precisam se tornar protagonistas no processo de substituição do atual paradigma para uma cultura focada na segurança. Sugere-se replicação deste estudo em outras instituições a fim de aprimorar o atual cenário de assistência à saúde.

\section{DESCRITORES}

Segurança do Paciente; Cultura Organizacional; Equipe de Enfermagem; Enfermagem Pediátrica. 


\section{RESUMEN}

Objetivo: Identificar la cultura de seguridad del paciente en urgencias pediátricas, en la perspectiva del equipo de enfermería. Método: Investigación cuantitativa, tipo survey transversal. Muestra compuesta de 75 profesionales del equipo de enfermería. Datos recolectados entre septiembre y noviembre de 2014, en tres Urgencias Pediátricas, aplicando el instrumento Hospital Survey on Patient Safety Culture. Datos sometidos al análisis descriptivo. Resultados: No fueron encontradas áreas de fuerza para la seguridad del paciente, siendo identificadas áreas con potencial de convertirse así: Expectativas y acciones del supervisor/jefatura para promoción de la seguridad del paciente y Trabajo en equipo. Como área crítica se identificaron: Respuesta no punitiva al error y Apoyo de la gestión hospitalaria para seguridad del paciente. El estudio señaló alejamiento entre la cultura de seguridad y las urgencias pediátricas; sin embargo, vislumbró posibilidades de transformación que contribuirán a la seguridad del paciente pediátrico. Conclusión: Los profesionales de enfermería necesitan hacerse protagonistas en el proceso de reemplazo del actual paradigma hacia una cultura enfocada en la seguridad. Se sugiere la replicación de este estudio en otras instituciones a fin de perfeccionar el actual escenario de asistencia sanitaria.

\section{DESCRIPTORES}

Seguridad del Paciente; Cultura Organizacional; Gupo de Enfermería; Enfermería Pediátrica.

\section{REFERENCES}

1. Konh LT, Corrigan JM, Donaldson MS. Errors in health care: a leading cause of death and injury. In: Konh LT, Corrigan JM, Donaldson MS. To err is human: building a safer health care system. Washington: Institute of Medicine; 2000. p. 26-48.

2. James JT. A new, evidence-based estimate of patient harms associated with hospital care. J Patient Saf. 2013;9(3):122-8.

3. Patterson MD, Geis GL, LeMaster T, Wears RL. Impact of multidisciplinary simulation-based training on patient safety in a paediatric emergency department. BMJ Qual Saf. 2013;22(5):383-93.

4. World Health Organization (WHO). The Launch of the World Alliance for Patient Safety: "Please do me no harm" [Internet]. Geneva: WHO; 2004 [cited 2014 Mar 23]. Available from: http://www.who.int/patientsafety/launch/en/

5. Brasil. Ministério da Saúde. Portaria n. 529, de $1^{\circ}$ de abril de 2013. Institui a Política Nacional de Segurança do Paciente (PNSP) [Internet]. Brasília; 2013 [citado 2014 abr. 2]. Disponível em: http://bvsms.saude.gov.br/bvs/saudelegis/gm/2013/prt0529_01_04_2013.html

6. Tomazoni A, Rocha PK, Souza S, Anders JC, Malfussi HFC. Patient safety culture at neonatal intensive care units: perspectives of the nursing and medical team. Rev Latino Am Enfermagem 2014;22(5):755-63.

7. Paese F, Dal Sasso GTM. Patient safety culture in Primary Health Care. Texto Contexto Enferm. 2013;22(2):302-10.

8. Cox ED, Carayon P, Hansen KW, Rajamanickam VP, Brown RL, Rathouz PJ, et al. Parent Perceptions of Children's Hospital Safety Climate. BMJ Qual Saf. 2013;22(8):664-71.

9. Tomazoni A, Rocha PK, Kusahara DM, Souza AIJ, Macedo TR. Evaluation of the patient safety culture in Neonatal Intensive Care. Texto Contexto Enferm. 2015;24(1):161-9.

10. Shaw KN, Ruddy RM, Olsen CS, Lillis KA, Mahajan PV, Dean JM, et al. Pediatric patient safety in emergency departments: unit characteristics and staff perceptions. Pediatrics. 2009;124(201):485-93.

11. Wegner W, Pedro ENR. Patient safety in care circumstances: prevention of adverse events in the hospitalization of children. Rev Latino Am Enfermagem. 2012;20 (3):427-34

12. Brasil. Ministério da Saúde. Cadastro Nacional de Estabelecimentos de Saúde - CNES [Internet]. Brasília; 2015 [citado 2015 jul. 17]. Disponível em: http://dados.gov.br/dataset/cnes

13. Reis CT, Languardia J, Martins M. Adaptação transcultural da versão brasileira do Hospital Survey On Patient Safety Culture: etapa inicial. Cad Saúde Publica. 2012; 28(11):2199-210.

14. Famalaro T, Yount ND, Burns WBMA, Flashner EMHA, Liu H, Sorra J. Hospital Survey on Patient Safety Culture 2016: user comparative database report. Rockville: Agency for Healthcare Research and Quality; 2016.

15. Brasil. Ministério da Saúde; Conselho Nacional de Saúde. Resolução n. 466, de 12 de dezembro de 2012. Dispõe sobre diretrizes e normas regulamentadoras de pesquisas envolvendo seres humanos [Internet]. Brasília; 2012 [citado 2014 jun. 29]. Disponível em: http://conselho. saude.gov.br/resolucoes/2012/Reso466.pdf

16. Wang X, Liu K, You LM, Xiang JG, Hu HG, Zhang LF, et al. The relationship between patient safety culture and adverse events: a questionnaire survey. Int J Nurs Stud. 2014;51(8):1114-22.

17. Verbeek-van Noord I, Wagner C, Van Dyck C, Twisk JW, Bruijne MC. Is culture associated with patient safety in the emergency department? A study of staff perspectives. Int J Qual Health Care. 2013;26(6):573-8.

18. Claro CM, Krocockz DVC, Toffolleto MC, Padilha KG. Adverse events at the Intensive Care Unit: nurses' perception about the culture of no-punishment. Rev Esc Enferm USP. 2011;45(1):162-7.

19. Souza FT, Garcia MC, Rangel PPSR, Rocha PK. Percepção da enfermagem sobre os fatores de risco que envolvem a segurança do paciente pediátrico. Rev Enferm UFSM. 2014;4(1):152-62. 